\title{
The Signal Sequence of Sporulation-Specific Glucoamylase Directs the Secretion of Bacterial Endo-1,4- $\beta-D-$ Glucanase in Yeast
}

\author{
Soon-Cheol Ahn², Eun-Ju Kim³, Sung-Sik Chunn', Yong-Kweon Cho', Ja-Young Moon ${ }^{1}$ \\ and Dae-Ook Kang * \\ ${ }^{1}$ Department of Biochemistry and Health Science, College of Natural Sciences, Changwon National University, Changwon 641-773, Korea
${ }^{2}$ Department of Microbiology and Immunology, School of Medicine, Pusan National University, Yangsan 626-870, Korea
${ }^{3}$ Chemistry Education Major, Division of Science Education, College of Education, Daegu University, Gyeongsan 712-714, Korea
${ }^{4}$ Department of Food Science, International University of Korea, Jinju 660-759, Korea
}

Received January 10, 2012 /Revised February 3, 2012 /Accepted February 20, 2012

\begin{abstract}
The sporulation-specific glucoamylase (SGA) of Saccharomyces diastaticus is known to be produced in the cytoplasm during sporulation. For the purpose of proving that SGA has secretory potential, we constructed a hybrid plasmid, pYESC25, containing the promoter and the putative signal sequence of the SGA fused in frame to the endo-1,4- 2 -D-glucanase (CMCase) gene of Bacillus subtilis without its own signal sequence. The recipient yeast strain of $S$. diastaticus YIY345 was transformed with the hybrid plasmid. CMCase secretion from $S$. diastaticus harboring pYESC25 into culture medium was confirmed by the formation of yellowish halos around transformants after staining with Congo red on a CMC agar plate. The transformant culture was fractionated to the extracellular, periplasmic, and intracellular fraction, followed by the measurement of CMCase activity. About $63 \%$ and $13 \%$ enzyme activity were detected in the culture supernatant (extracellular fraction) and periplasmic fraction, respectively. Furthermore, ConA-Sepharose chromatography, native gel electrophoresis, and activity staining revealed that CMCase produced in yeast was glycosylated and its molecular weight was larger than that of the unglycosylated form from B. subtilis. Taking these findings together, SGA has the potential of secretion to culture medium, and the putative signal sequence of SGA can efficiently direct bacterial CMCase to the yeast secretion pathway.
\end{abstract}

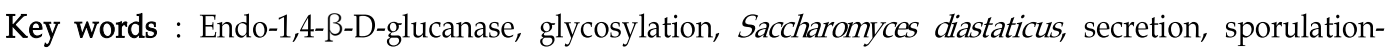
specific glucoamylase

\section{Introduction}

Eukaryotic cells synthesize many different proteins, each of which must reach a specific intracellular location or extracellular location to perform its function. Some proteins are transported to specific membrane-bound organelles. The proteins transported to extracellular location have a signal sequence directing proteins to their target sites, which is usually a short stretch of amino acids at the $\mathrm{NH}$-terminus of the protein itself [17].

Signal sequences target nascent polypeptides to lumen of endoplasmic reticulum, a component of the secretion pathway. There are three distinctive structures of signal peptides from various proteins; a positively charged n-region, followed by a hydrophobic h-region and a neutral but polar c-region. The (-3,-1)-rule states that small and neutral amino

*Corresponding author

Tel : +82-55-213-3554, Fax : +82-55-213-3550

E-mail : dokang@changwon.ac.kr acid residues should be at -3 and -1 position for correct cleavage [10].

During meiosis in Saccharomyces cerevisiae and Saccharomyces diastaticus, the polysaccharide, glycogen is first synthesized and then degraded during the period of spore maturation. Sporulation-specific glucoamylase (SGA) is responsible for the glycogen catabolism [1]. This enzyme has been regarded as an intracellular enzyme, because the enzyme is detected in the intracellular region during sporulation. Other groups reported that the SGA is glycosylated and compartmented in cell organelle, vacuole. This result suggested that the SGA may contain the signal sequence for entry into the secretion pathway of the cell $[6,12,13]$.

We have previously cloned the SGA gene from $S$. diastaticus and expressed it in vegetative stage [4]. Moreover, we purified and characterized the SGA from the transformant cell harboring the SGA gene [5]. We found that the major proportion of enzyme activity was detected in extracellular region. This suggests that the SGA has secretion 
potential. To assess the signal sequence of the SGA, we tried several times $\mathrm{N}$-terminal amino acid sequencing with the purified SGA enzyme. But we could not get the data because N-terminal amino acid was blocked.

We used another approach to prove that the SGA has the signal sequence. In this paper, we constructed a hybrid plasmid containing the SGA promoter and nucleotide sequences encoding putative signal peptide fused to Bacillus subtilis endo-1,4- $\beta$-D-glucanase (CMCase) gene lacking its own promoter and signal sequence, and monitored localization of CMCase activity and the extent of glycosylation.

\section{Materials and Methods}

\section{Bacterial strains culture media}

Escherichia coli TOP10 [F- mcrA $\triangle$ (mrr-hsdRMS-mcrBC) $\phi$ 80lacZ $\triangle$ M15 $\triangle$ lacX74 deoR recA1 araD139 $\triangle$ (ara-leu)7697 galU galK rpsL(Str ${ }^{R}$ endA1 nupG] was used for gene cloning and plasmid amplification. E. coli was grown in Luria-Bertani (LB) broth ( $1 \%$ tryptone, $0.5 \%$ yeast extract, $1.0 \% \mathrm{NaCl})$.

The yeast $S$. diastaticus YIY345 (a, ura3-52 leu2-3,112 his4 sta inh ${ }^{a}$ was used as a host strain for the expression of bacterial CMCase gene. Yeast cells were grown in YPD broth $\left(1.0 \%\right.$ yeast extract, $2.0 \%$ peptone, $2.0 \%$ dextrose) at $30^{\circ} \mathrm{C}$. The transformants of $S$. diastaticus YIY345 were cultured in YNBD medium $(0.67 \%$ Bacto-yeast nitrogen base without amino acids, $2.0 \%$ dextrose) supplemented with $20 \mu \mathrm{g} / \mathrm{ml}$ of L-histidine $\cdot \mathrm{HCl}$ and $30 \mu \mathrm{g} / \mathrm{ml}$ of L-leucine.

\section{Prediction of SGA signal sequence}

Thirty amino acid residues of N-terminal SGA were analyzed to identify a signal sequence in the SGA using TatP 1.0 server http://www.cbs.dtu.dk/services/TatP-1.0/. The S-score (value), C-score and Y-score of each amino acid of $30 \mathrm{~N}$-terminal residues were obtained from analysis and Y-score was plotted. The cleavage site of signal sequence is generally located in amino side peptide bond of amino acid with the maximal C- and Y-score [10].

\section{Construction of hybrid plasmid}

Two plasmids, pYES12 [4] and pUEC19, were used for the construction of the hybrid plasmid, pYSC25. The plasmid pYES12 contained a 3.9-kb BanHI fragment encoding the SGA at the BanHI site of YEp24 vector. The plasmid pUEC19 contains structural gene of B. subtilis CMCase. The HadII site is located at the 40th codon from the initiation codon.
The HindII site is located immediately after stop codon of the CMCase. After cutting CMCase gene with HadII and HindII, both termini were converted to blunt ends by Klenow enzyme. The blunt ended 1.4-kb CMCase gene was inserted in Smal site of pUC19 and designated as pUEC19. Thus, the CMCase in pUEC19 consists of only structural region lacking 29-amino acid signal peptide and ten amino acid residues in the N-terminal region of mature CMCase.

The pYES12 was treated with $X$ hd and Smal to remove the structural region of the SGA. About 8.0-kb DNA fragment containing the promoter and 24-amino acid residues of the putative signal sequence of the SGA, was purified from agarose gel. The plasmid, pUEC19 was partially digested with EcoRI and its termini were converted to blunt ends with Klenow enzyme and then cut with Sall. The resulting 1.4-kb DNA fragment of the CMCase was recovered and ligated with purified 8.0-kb fragment, generating a recombinant plasmid, pYSC25 (Fig. 2).

\section{Transformation}

E. coli transformation was carried out by $\mathrm{CaCl}_{2}$ method [15]. Ttransformants were selected on LB plates supplemented with $100 \mathrm{\mu g} / \mathrm{ml}$ of ampicillin. Yeast transformation was carried out by Dohmen method [3]. Yeast transformants were screened on YNBD agar plate containing L-leucine and L-histidine $\cdot \mathrm{HCl}$. Yeast transformants secreting CMCase was selected on YNBD plate containing 1\% carboxymethylcellulose (CMC) by Congo red staining for $30 \mathrm{~min}$ and then washing with $1.0 \mathrm{M} \mathrm{NaCl}$ solution [16].

\section{Subcellular fractionation of yeast cell cultures}

Yeast cells were grown in $200 \mathrm{ml}$ of YPD medium at $30^{\circ} \mathrm{C}$ for 2 days. Culture supernatant was recovered by centrifugation and then concentrated to 5 times by ultrafiltration (PM10). This concentrated culture broth was regarded as extracellular fraction, secreted enzyme. The cell pellets were resuspended in $20 \mathrm{ml}$ of protoplasting buffer $\left(0.1 \mathrm{M} \mathrm{K}_{2} \mathrm{HPO}_{4}\right.$, $0.5 \mathrm{M} \mathrm{KCl}, \mathrm{pH} \mathrm{7.0)}$ and mixed with $2 \mathrm{ml}$ of $0.6 \mathrm{M}$ EDTA. The mixture was incubated for $40 \mathrm{~min}$ at $30^{\circ} \mathrm{C}$ with gentle shaking and centrifuged. The cell pellet was resuspended in $20 \mathrm{ml}$ of protoplasting buffer and $200 \mu \mathrm{l}(5 \mathrm{mg} / \mathrm{ml})$ of zymolyase 100T was added. The mixture was incubated for $40 \mathrm{~min}$ at $30^{\circ} \mathrm{C}$ with gentle shaking. Protoplasts were harvested with centrifugation and supernatant was regarded as periplasmic fraction. The protoplast was washed twice with potassium phosphate buffer and resuspended in $10 \mathrm{ml}$ of 
DW. The mixture were sonicated and centrifuged. The supernatant was recovered as intracellular fraction [2].

\section{CMCase activity assay}

The CMCase activity was determined by measuring the release of reducing ends from $\mathrm{CMC}$ substrate by dinitrosalicylic acid (DNS) method [9]. The reaction mixture contained $0.5 \mathrm{ml}$ of appropriately diluted enzyme solution and $0.5 \mathrm{ml}$ of $1 \% \mathrm{CMC}$ in $0.05 \mathrm{M}$ citrate buffer, $\mathrm{pH}$ 5.5. After the incubation for $30 \mathrm{~min}$ at $60^{\circ} \mathrm{C}, 3 \mathrm{ml}$ DNS solution was added, and boiled for $5 \mathrm{~min}$. The absorbance was measured at $550 \mathrm{~nm}$. One unit of enzyme activity corresponded to 1 umole of glucose equivalents liberated per min from CMC.

\section{ConA-Sepharose affinity chromatography}

The fractionated solutions were applied to a ConASepharose column $(1.0 \times 5 \mathrm{~cm})$ equilibrated with $10 \mathrm{mM}$ potassium phosphate buffer ( $\mathrm{pH} 7.0$ ) containing $0.5 \mathrm{M} \mathrm{KCl}$. After the column was washed with the same buffer, the enzyme was eluted with $0.25 \mathrm{M}$ methyl-a-D-mannoside in the same buffer and its CMCase activity was measured.

\section{Native gel electrophoresis}

Polyacrylamide gel electrophoresis was performed in 9\% polyacrylamide gel in the absence of SDS as described by Laemmli [11]. Enzyme samples (10 pl) were applied to the gel and electrophoresis was conducted at room temperature at a constant current of $40 \mathrm{~mA}$ for $2 \mathrm{hr}$. Upon completion of electrophoresis, the gels were submerged in $50 \mathrm{mM}$ citrate buffer ( $\mathrm{pH}$ 5.5) for $30 \mathrm{~min}$. The equilibrated gel was blotted on CMC agar replica containing $0.5 \% \mathrm{CMC}$ and $1 \%$ agarose in $50 \mathrm{mM}$ citrate buffer (pH 5.5) and then incubated at $40^{\circ} \mathrm{C}$ for $1 \mathrm{hr}$. The CMC agar replica was stained with Congo red solution $(0.5 \mathrm{mg} / \mathrm{ml})$ for $30 \mathrm{~min}$ to visualize light yellowish activity bands [14].

\section{Results and Discussion}

\section{Construction of hybrid plasmid}

S-score, C-score and Y-score analysis of $30 \mathrm{~N}$-terminal amino acids showed that S-sore gradually increased to maximal value at the 10th Lys and then decreased to the lowest value at the 25th Leu (data not shown), and the 25th Leu had the highest C-score of 0.665 and Y-score of 0.439 (Fig. 1). These analyses strongly suggest that most likely signal sequence cleavage site is between the 24th Ala and the 25th

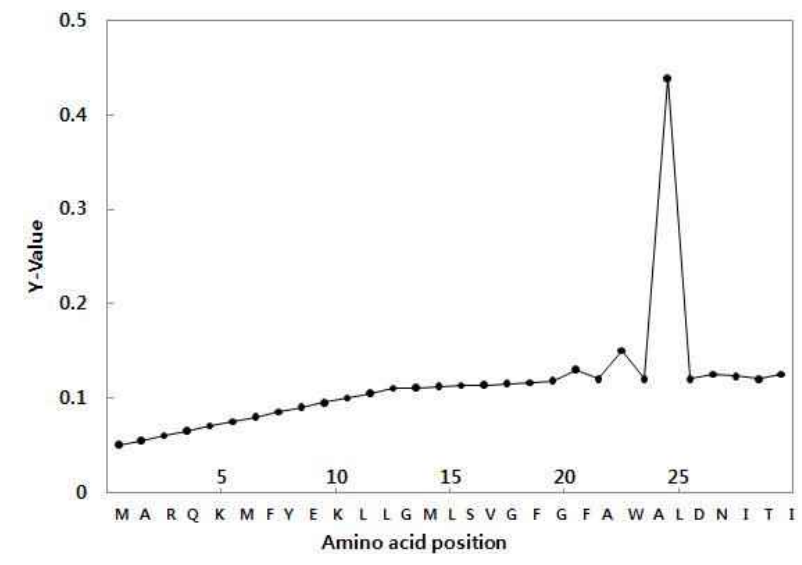

Fig. 1. Prediction of signal peptide cleavage site of the SGA. The numbering of the amino acid residues begins at the translation initiation codon, methionine. The signal sequence cleavage site predicted by cleavage probabilities is between the 24th Ala and the 25th Leu.

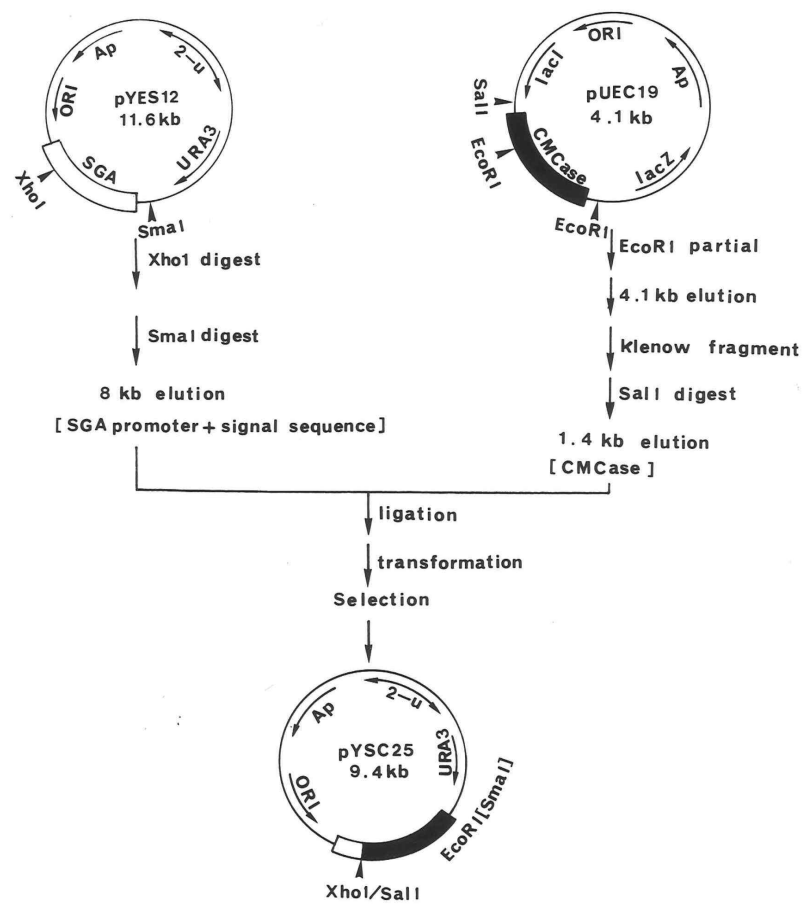

Fig. 2. Construction of a recombinant plasmid, pYSC 25. The open bar represents the open reading frame of the SGA gene and the closed bar the structural gene of B. subtilis CMCase.

Leu and the signal peptide of the SGA consists of 24-amino acid residues [10]. Moreover, the Ala at the 22nd and the 24th codon are consistent with the $(-3,-1)$ rule [18].

The hybrid plasmid, pYESC25 was made according to the procedures shown in Fig. 2. This plasmid contains the promoter and signal sequence of the SGA and structural region 
of $B$. subtilis CMCase. The nucleotide and amino acid sequences around the fusion site between the SGA signal peptide and the CMCase gene are shown at Fig. 3. The 24-amino acid residues from the initiation codon, Met to the 24th codon, Ala are the putative signal peptide of the SGA. The structural region of the CMCase starts at the 32nd codon. There are more 6 amino acid residues between the signal peptide and structural CMCase, which were originated from the SGA and polylinker cloning sites of the vector, pUC19. The correctly recombined plasmid, pYEC25 was selected by restriction enzyme mapping and nucleotide sequencing analysis and then introduced into $S$. diastaticus YIY345 by transformation.

\section{Secretion and glycosylation of Bacillus CMCase}

When transformants containing the pYSC25 were grown on YNBD plate containing 1\% CMC and stained with Congo red, the yellowish halos were shown around the colonies (Fig. 4B). These halos indicate that the CMCase was secreted into culture medium by the aid of the signal sequence of the SGA. However, there were no halos around host strain, S. diastaticus YIY345 (Fig. 4A).

To assay CMCase activity in the different cellular regions, we cultured transformant cells in $200 \mathrm{ml}$ of YPD broth and then fractionated culture into extracellular, periplasmic and cytoplasmic CMCase according to the methods described in Materials and Methods. First, these prepared enzyme solutions $(20 \mu \mathrm{l})$ were loaded in wells on agar plates containing

\begin{tabular}{|c|c|c|c|c|c|c|c|c|c|c|}
\hline 1 & & & & 5 & & & & & 10 & \\
\hline ATG & GCA & AGA & CAA & AAG & ATG & TTT & TAT & $\mathrm{AAC}$ & AAA & TTA \\
\hline Met & Ala & $\operatorname{Arg}$ & Gln & Lys & Met & Phe & Tyr & Asn & Lys & Leu \\
\hline
\end{tabular}

\begin{tabular}{lllllllllll} 
& \multicolumn{1}{c}{15} & & & & & 20 & & \\
CTC & GGC & ATG & CTC & AGC & GTA & GGA & TTC & GGG & TTT & GCT \\
Leu & Gly & Met & Leu & Ser & Val & Gly & Phe & Gly & Phe & Ala \\
\hline
\end{tabular}

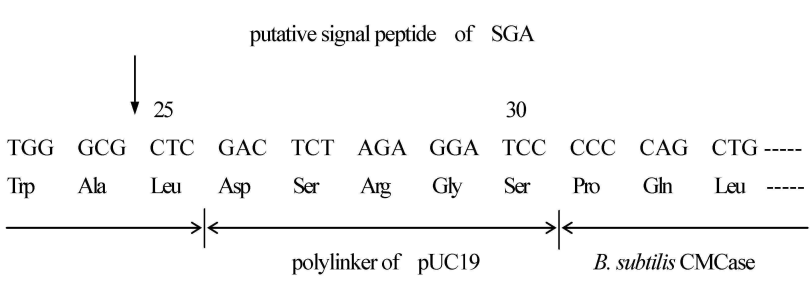

Fig. 3. The nucleotide and amino acid sequences around the fusion sites of the SGA and the CMCase gene. The corresponding amino acid sequence is given in three-letter code. The arrow indicates probable cleavage site of the SGA signal sequence.
A

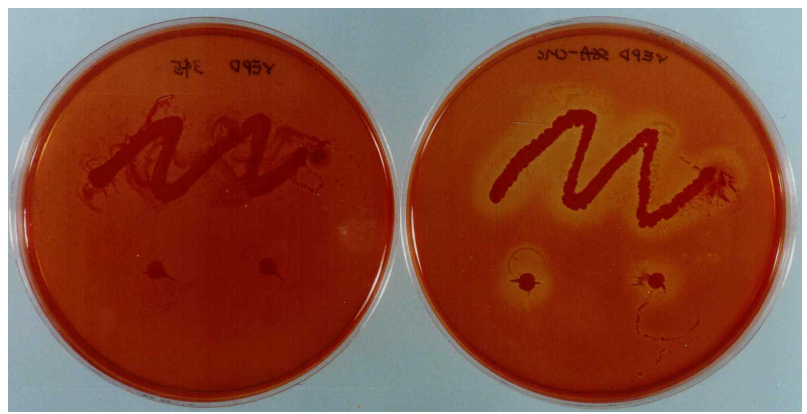

Fig. 4. Secretion of CMCase by yeast transformant. Recipient cells, S. diastaticus YIY 345 (A) and transformant cells containing pYSC 25 (B) were cultured on minimal agar media supplemented with $1 \% \mathrm{CMC}$ and stained with Congo red. The yellowish halos indicate that CMCase was secreted into culture medium by the signal sequence of the SGA.

$1 \% \mathrm{CMC}$ and then incubated at $40^{\circ} \mathrm{C}$ for $30 \mathrm{~min}$. The halos around wells appeared after Congo red staining (data not shown). CMCase activity was detected in all fractionated sample; extracellular, periplasmic and cytoplasmic region. The enzyme activity of each region was shown in Table 1. The total activity was lower than expected, which may be due to the weak promoter activity of the SGA gene. Regulatory region like upstream activator sequence could be missing in relatively short promoter in the cloned SGA gene [8]. Because of the absence of regulatory region, we could purify the SGA from transformant containing the SGA gene at the vegetative stage [5].

The CMCase contains two potential N-glycosylation sites (Asn-X-Ser/Thr). N-linked glycosylation of proteins occurs during the passage through endoplasmic reticulum (ER) and Goli apparatus which are components of yeast secretion pathway. If the CMCase in the culture medium and periplasmic region was glycosylated, it would strongly suggest that the enzyme is secreted through the yeast secretory pathway. This was confirmed by ConA-Sepharose affinity chromatography and native gel electrophoresis. The CMCase from extracellular, periplasmic and cytoplasmic region was loaded onto ConA-Sepharose column. The enzymes in all regions were tightly bound to the resin and specifically eluted with methyl-a-D-mannoside (Table 1). This implies that yeast CMCase was glycosylated and putative SGA signal sequence functions in targeting bacterial CMCase to ER, the first step of yeast secretion pathway.

For the comparison of molecular size of glycosylated 
Table 1. Subcellular localization of CMCase activity in S. diastaticus YIY345 transformant

\begin{tabular}{lccc}
\hline Subcellular fraction & CMCase activity (unit) & Relative activity $(\%)$ & Glycosylation $^{\text {a }}$ \\
\hline Extracellular & 33 & 62.7 & + \\
Periplasmic & 7 & 13.3 & + \\
Intracellular & 12.6 & 24.0 & + \\
\hline
\end{tabular}

Yeast transformant strain was cultured in $200 \mathrm{ml}$ of YPD medium at $30^{\circ} \mathrm{C}$ for 2 days.

${ }^{\mathrm{a}}$ One unit was defined as the amount of enzyme releasing $1 \mu$ mole of glucose equivalents from CMC per minute.

${ }^{\mathrm{b}}$ The degree of glycosylation was verified by Con-A Sepharose affinity chromatography and CMCase activity assay of flow-through and eluted fraction.

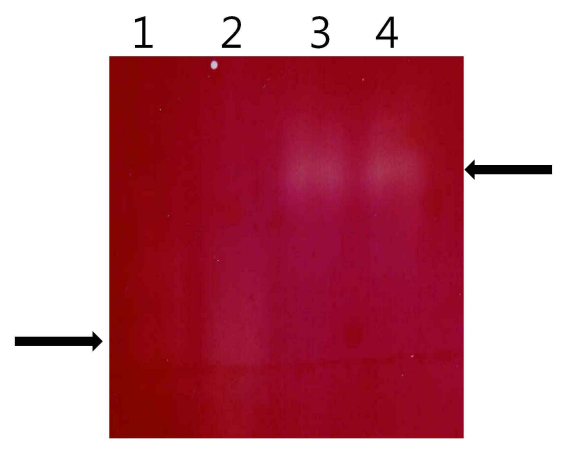

Fig. 5. Native polyacrylamid gel electrophoresis of CMCase. Each sample $(10 \mu \mathrm{l})$ was loaded on $9.0 \%$ polyacrylamide gel and electrophoresis was conducted for $2 \mathrm{hr}$. The polycrylamid gel was blotted on CMC agar replica and the replica was stained with Congo red. Lane 1, B. subtilis CMCase; 2, intracellular fraction; 3, periplasmic fraction; 4 , extracellular fraction.

CMCase from yeast with unglycosylated CMCase from $B$. subtilis, native gel electrophoresis was carried out and CMCase was detected with activity staining. Fig. 5 showed that extracellular and periplasmic CMCase from yeast were much larger than the CMCase from bacteria. This means that the CMCase from yeast was hyper-glycosylated and molecular weight increased to more than $150 \mathrm{kDa}$ (Fig. 5. right upper arrow). The MW of the CMCase from B. subtilis was reported to be $33 \mathrm{kDa}$ [11]. Cytoplasmic CMCase was partly glycosylated and the size of MW was similar to bacterial CMCase (Fig. 5. left lower arrow).

In conclusion, we proved that the SGA has secretory potential in that bacterial CMCase directed by the putative SGA signal sequence was secreted to extracellular region via yeast secretion pathway. This might be the first report about heterologous protein secretion using putative signal sequence of the SGA. The SGA signal sequence could be utilized for the secretory production of other heterologous proteins in Saccharomyces species.

\section{Acknowledgement}

This research is financially supported by Changwon National University in 2009-2010.

\section{References}

1. Colonna, W. J. and P. T. Magee. 1978. Glycogenolytic enzymes in sporulating yeast. J. Bacteriol. 134, 844-853.

2. Curry, C., N. Gilkes, G. O'Neill, JR. R. C. Miller, and N. Skipper. 1988. Expression and secretion of a Cellulomonas fimi exoglucanase in Saccharomyces cerevisiae. Appl. Environ. Microbiol. 54, 476-484.

3. Dohmen, R. J., A. W. M. Strasser, C. B. Höner, and C. P. Hollenberg. 1991. An efficient transformation procedure enabling long-term storage of competent cells of various yeast genera. Yeast 7, 691-692.

4. Kang, D. O., I. K. Hwang, W. K. Oh, H. S. Lee, S. C. Ahn, B. Y. Kim, T. I. Mheen, and J. S. Ahn. 1999. Molecular cloning and analysis of sporulation specific glucoamylase (SGA) gene of Saccharomyces diastaticus. J. Microbiol. 37, 35-40.

5. Kim, E. J., J. S. Ahn, and D. O. Kang. 2010. Characterization of sporulation-specific glucoamylase of Saccharomyces diastaticus. J. Life Sci. 20, 683-690.

6. Kleinman, M. J., A. E. Wilkinson, I. P. Wright, and I. H. Evands. 1988. Purification and properties of an extracellular glucoamylase from a diastatic strain of Saccharomyces cerevisiae. Biochem J. 249, 163-170

7. Laemmli, U. K. 1970. Cleavage of structural proteins during the assembly of the head of bacteriophage T4. Nature 227, 680-685.

8. Lambrechts, M. G., I. S. Pretorius, J. Marmur, and P. Sollitti. 1995. The S1, S2 and SGA1 ancestral genes for the STA glucoamylase genes all map to chromosome IX in Saccharomyces cerevisiae. Yeast 11, 783-787.

9. Miller, G. L. 1959. Use of dinitrosalicylic acid reagent for determination of reducing sugar. Anal. Chem 55, 952-959.

10. Nielsen, H., J. Engelbrecht, S. Brunak, and G. von Heijne. 1997. Identification of prokaryotic and eukaryotic signal peptides and prediction of their cleavage sites. Protein Engineer. 10, 1-6.

11. Park, S. H., H. K. Kim, and M. Y. Pack. 1991. Characterization and structure of the cellulase gene of 
Bacillus subtilis BSE 616. Agric. Biol. Chem 55, 441-448.

12. Pretorius, L. S., M. G. Lambrechts, and J. Marmur. 1991. The glucoamylase multigene family in Saccharomyces cerevisiae var. diastaticus: an overview. Crit. Rev.Biochem. Mol. Biol. 26, 53-76.

13. Pugh T. A., J. C. Shah, P. T. Magee, and M. J. Clancy. 1989. Characterization and localization of the sporulation glucoamylase of Saccharomyces cerevisiae. Biochim Biophys. Acta 994, 200-209.

14. Schwarz W. H., K. Bronnenmeier, F. Grabnitz, and W. L. Staudenbauer. 1987. Activity staining of cellulases in polyacrylamide gels containing mixed linkage beta-glucans. Anal. Biochem 164, 72-77.
15. Seidman, C. E. 1988. Escherichia coli, plasmid, and bacteriophages, In: Current protocols in molecular biology. Eds. Ausubel, F. M., Brent, R., Kingston, R. E., Moore, D. D., Seidman, J. G., Smith, J. A., and Struhl, K. John Wiley \& Sons Inc. New York, unit 1.8.1-1.8.3.

16. Theater, R. M. and P. J. Wood. 1982. Use of Congo red polysaccharide interactions in enumeration and characterization of cellulolytic bacteria from the bovine rumen. Appl. Enviran. Microbiol. 43, 777-780.

17. Verner, K. and G. Schatz. 1988. Protein translocation across membranes. Science 241, 1307-1313.

18. von Heinje, G. 1983 Patterns of amino acids near signal-sequence cleavage sites. Eur. J. Biochem 133, 17-21.

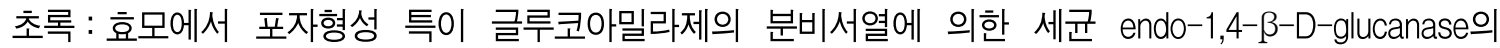 분비 \\ 안순철 $^{2} \cdot$ 김은주 $^{3} \cdot$ 전성식 $^{4} \cdot$ 조용권 ${ }^{1} \cdot$ 문자영 $^{1} \cdot$ 강대욱 ${ }^{1}$ \\ ( ${ }^{1}$ 창원대학교 자연과학대학 보건의과학과, ${ }^{2}$ 부산대학교 의과대학 미생물학교실, ${ }^{3}$ 대구대학교 사범대학 과학교육 학부 화학교육전공, ${ }^{4}$ 한국국제대학교 식품의약학과)}

효모 Saccharomyces diastaticus 가 포자형성기에 세포질에서 생산된다고 알려진 포자형성 특이 glucoamylase (SGA)가 세포 외로 분비되는 단백질임을 증명하고자 S. dastaticus의 SGA promoter와 예상되는 분비신호서열 다 음에 reporter gene으로 사용한 고초균의 CMCase 구조유전자를 융합한 재조합 플라스미드 pYSC25를 제작하고 수주세포인 S. diastaticus YIY345에 형질전환 하였다. 형질전환체를 $1 \% \mathrm{CMC}$ 를 포함하는 최소한천배지에서 배양 한 후 Congo red 염료로 염색하여 생성된 투명환으로부터 SGA의 분비서열에 의해 세균의 CMCase가 효모세포 외로 분비되는 것을 확인하였다. 효모세포부위 별 CMCase의 활성분포를 측정하여 SGA 분비서열의 분비효율을 추정하기 위해 효모세포 배양액을 배양상등액, periplasmic 및 세포질 분획으로 나눈 다음 효소활성을 측정한 결 과 CMCase 활성의 $76 \%$ 가 배양상등액과 periplasmic 부위에 존재하였으며 N-연결형 당쇄가 일어났으므로 SGA 분비서열은 효과적으로 작용함을 알 수 있었다. 대조균인 고초균에서 생산된 CMCase에서는 당쇄가 일어나지 않은 것을 확인하였다. 이상의 결과로부터 SGA는 아미노 말단에 존재하는, 24 개의 아미노산으로 구성된 분비서 열을 보유한 분비성 단백질임을 확인하였다. 